The Bangladesh Veterinarian (2014) 31(2): 84 - 90

\title{
Performances of commercial hybrid broiler in villages of Bangladesh
}

\author{
F Islam, MS Hossain, SC Sarker ${ }^{*}$ and MS Hossain ${ }^{2}$ \\ Department of Animal Breeding and Genetics, Faculty of Animal Husbandry, Bangladesh \\ Agricultural University, Mymensingh-2202, Bangladesh
}

\begin{abstract}
A total of 20 broiler farms were enumerated to evaluate the production performance of broiler birds and farm management status at rural villages of Mymensingh Sadar (district headquarters) Upazila under Mymensingh district in Bangladesh. Data were collected on day-old chick weight (DOCW), live broiler weight at market age (MW), feed conversion ratio (FCR), average daily body weight gain (ADG), mortality up to age of marketing (MTRT) during June and July, 2014 using a pre-tested questionnaire by door-to-door visit. Seventeen out of 20 farms had broiler houses with gable type roof of corrugated iron sheet (CIS), all farmers were using rice husk as litter materials and electric brooder for brooding birds for 7 days. To minimize heat stress, $65 \%$ farmers used electric fan and drinking water, and to minimize cold stress quantities of litter materials were increased and vitamin $C$ was supplied with lukewarm drinking water. Newcastle Disease (ND) and Infectious Bursal Disease (IBD) vaccines were used by all farmers. Mean ADG, MW, DOCW and MTRT were $45.3 \pm 1.2 \mathrm{~g} / \mathrm{bird}, 1581.6 \pm 46.1 \mathrm{~g} / \mathrm{bird}, 54.7 \pm 3.0 \mathrm{~g} / \mathrm{bird}$ and $5.2 \pm$ $1.0 \%$, respectively. Feed from two different companies had no significant effect on FCR and MTRT but feed company affected the ADG significantly. DOCW, farm size and farmer's education did not affect ADG, FCR and MTRT significantly. (Bangl. vet. 2014. Vol. 31 , No. $2,84-90)$
\end{abstract}

\section{Introduction}

In the last two decades the poultry sector in Bangladesh has grown at an annual rate of around $20 \%$. It has improved livelihoods and food, and reduced the dependence on beef and mutton as animal protein sources (Islam et al., 2014). This industry is committed to supplying the nation a cheap source of good quality animal protein (Akter and Uddin, 2009), and reducing poverty (Islam et al., 2014). Investment in the sector stands at about Taka 200 billion (US\$1 = Taka 80). There are over a 100 thousand poultry farms across the country, eight grand-parent (GP) stock farms, 130 parent stock farms and hatcheries, and 50 or 60 poultry feed mills. About five million people are involved, directly and indirectly, with the industry. A large section of marginalized rural people earn their living through this industry. Of the $18.6 \%$ of the

\footnotetext{
1PhD student, Department of Agricultural Economics, Faculty of Agricultural Economics and Rural Sociology, Bangladesh Agricultural University, Mymensingh-2202, Bangladesh

${ }^{2}$ Country Manager Bangladesh, Sri Lanka and Nepal, ISA (Institut De Selection Animale), A Hendrix

Genetics Company, BV

*Corresponding author:- E-mail: subhashsarker@yahoo.com
} 
GDP that comes from agriculture, one-third is from the poultry industry (Khaled, 2014). Profitability of broiler production involves planning, demand assessment, integration of activities to bring down the cost of production, foresight into market prices, assessment of cost-benefits and the rate of returns (Sultana et al., 2012). Performance of a broiler farm mainly depends on breed, feed and farm management. Study of performance of rural commercial broilers is scanty. The present study was undertaken to evaluate the performance farm management status of hybrid commercial broiler farming in local villages of Bangladesh.

\section{Materials and Methods}

The study investigated broiler production performance and farm management in 20 farms in the villages namely Beltoli, Borobila and Vabkhali of Mymensingh Sadar Upazila during June and July 2014. Data were collected by door to door visit on dayold chick weight (DOCW), live broiler weight at market age (MW), average daily body weight gain (ADG), feed conversion ratio (FCR), and mortality rate up to age of marketing (MTRT) with the help of a pre-tested questionnaire. ADG, FCR and MTRT were calculated using the following formulae:

$$
\begin{aligned}
& \mathrm{ADG}=\frac{\text { Live weight of bird }(\mathrm{g}) \text { at marketing day }- \text { day }- \text { old weight }(\mathrm{g})}{\text { Age in days of bird at marketing }} \\
& \mathrm{FCR}=\frac{\text { Total feed }(\mathrm{kg}) \text { consumed up to the age of marketing }}{\text { Live weight }(\mathrm{kg}) \text { of bird at marketing }} \\
& \text { MTRT }=\frac{\text { Total birds dead up to the age of marketing }}{\text { Total day-old birds loaded into the house }} \times 100
\end{aligned}
$$

A total of 21600 Ross hybrid broiler birds from 19 farms out of 20 farms were evaluated but the birds of the rest one farm was not taken in consideration because this farm was rearing hybrid broiler bird other than Ross (in 19 broiler farms there were 21600 Ross and in the other one broiler farm there were 2000 Cobb-500 birds). However, data on education, experience and training of farmers house type, litter material, brooder type and brooding period, feed company, standby power, vaccination, medication, de-worming, heat and cold stress management, drinks and growth promoters were documented from all (20) enumerated farms.

\section{Statistical analyses}

Farm management data were analysed using frequency and descriptive statistics menu in SPSS 11.5 software package. The performance means were separated using DMRT, and least square means were calculated using GLM model in SPSS 11.5 software package:

Yijk $=\mu+F i+C j+e ~ i j k$ 
Where, Yijkl = Dependent variables (ADG, FCR and MTRT)

$\mu=$ Overall population mean for any trait

$\mathrm{Fi}=$ Effect of ith feed company (where $\mathrm{i}=1$ or 2 )

$\mathrm{C} j=$ Effect of $\mathrm{jth}$ day old chick's body weight group (where $\mathrm{j}=1,2$ or 3 )

e ijk = Random residual error associated with Yijk observation.

\section{Results and Discussion}

\section{Farm background}

About $40 \%$ farmers had junior level education, 50\% higher secondary level education and $10 \%$ were graduates; $15 \%$ got training on poultry rearing and $85 \%$ had no training on broiler farming (Table 1). However $25 \%$ farmers had experience of broiler farming for less than 3 years while $75 \%$ had experience for more than 3 years. The results on education level were in line with Sultana et al. (2012) and Rahman et al. (2002). About $25 \%$ were small farms (500 - 800 birds), 50\% medium (1000-1600 birds) and the remaining large $(2000$ - 3000 birds). Similar results were reported by Sultana et al. (2012). About 95\% farmers reared Ross, while the rest reared Cobb 500 commercial hybrids: this result differed from previous reports (Hauque, 2005; Sharma, 2003; Sultana et el., 2012), where most farmers reared Cobb-500 commercial hybrids. This information indicated that broiler farming at rural level of Bangladesh was dominated by farmers with higher secondary level education or less.

Table 1. Farmers' education and farm size

\begin{tabular}{llc|c}
\hline & & Number of farmers & $\%$ \\
\hline Level of education & Junior & 8 & 40 \\
& Secondary & 10 & 50 \\
& Undergraduate & 2 & 10 \\
\hline Training on broiler & Yes & 3 & 15 \\
rearing & No & 17 & 85 \\
\hline Experience & Below 3 years & 5 & 25 \\
& 3 years and above & 15 & 75 \\
\hline Farm size & Small $(500-800$ birds) & 5 & 25 \\
& Medium $(1000-1600$ birds) & 10 & 50 \\
& Large $(2000-3000$ birds) & 5 & 25 \\
\hline Commercial hybrid & Cobb-500 & 1 & 5 \\
broiler strains reared & Ross & 19 & 95 \\
\hline
\end{tabular}

\section{Farm management}

Seventeen broiler houses had gable type roof (Table 2) with corrugated iron sheet (CIS), one had polyethylene, one had roof of CIS and one had other types. All farmers 
were using rice husk as litter; $25 \%$ of farmers used disposed litter as fertilizer, $35 \%$ as fish feed and the rest for other purposes. All farmers were using electric brooders and brooded their birds for 7 days. Only $5 \%$ of farmers were using generator as standby power supply for brooding. About $60 \%$ farmers were using hazak (a traditional lamp locally calls hazak, in which lamp, oil burns and high intensity light with heat is being generated) and 35\% farmers were using hurricane lanterns as standby power supplier.

Table 2. Factors associated with broiler farming in the villages of Mymensingh Sadar Upazila in Mymensingh district

\begin{tabular}{|c|c|c|c|}
\hline & & Number & $\%$ \\
\hline \multirow[t]{4}{*}{ Roof type of houses } & Gable type with CIS & 17 & 85 \\
\hline & Shed type with CIS & 1 & 5 \\
\hline & Shed type with polyethylene & 1 & 5 \\
\hline & Other type & 1 & 5 \\
\hline \multirow[t]{2}{*}{ Litter materials used } & Rice husk & 20 & 100 \\
\hline & Other & 0 & 0 \\
\hline \multirow[t]{3}{*}{ Uses of disposed litter } & Fertilizer & 5 & 25 \\
\hline & Fish feeding & 7 & 35 \\
\hline & Other & 8 & 40 \\
\hline \multirow[t]{2}{*}{ Brooding system } & Electric brooder & 20 & 100 \\
\hline & Other & 0 & 0 \\
\hline \multirow[t]{2}{*}{ Brooding period } & 7 days & 20 & 100 \\
\hline & More than 7 days & 0 & 0 \\
\hline \multirow{3}{*}{$\begin{array}{l}\text { Standby power supply } \\
\text { during brooding }\end{array}$} & Generator & 1 & 5 \\
\hline & Hazak & 12 & 60 \\
\hline & Hurricane lantern & 7 & 35 \\
\hline \multirow[t]{2}{*}{ Heat stress management } & $\begin{array}{l}\text { Use electric fan in the house and supply } \\
\text { cold water as drink }\end{array}$ & 13 & 65 \\
\hline & $\begin{array}{l}\text { Use electric fan in the house and supply } \\
\text { cold water with vitamin C as drink }\end{array}$ & 7 & 35 \\
\hline \multirow[t]{3}{*}{ Cold stress management } & $\begin{array}{l}\text { Increased litter materials and used warm } \\
\text { drinking water with vitamin C }\end{array}$ & 13 & 65 \\
\hline & $\begin{array}{l}\text { Increased litter materials and used } \\
\text { vitamin } C \text { in drinking water }\end{array}$ & 3 & 15 \\
\hline & $\begin{array}{l}\text { Increased litter materials and used mild } \\
\text { hot drinking water }\end{array}$ & 4 & 20 \\
\hline \multirow{2}{*}{$\begin{array}{l}\text { Drinks during housing } \\
\text { the day-old chicks }\end{array}$} & Water with oral saline and vitamin $C$ & 17 & 85 \\
\hline & $\begin{array}{l}\text { Water with oral saline, glucose and } \\
\text { vitamin C }\end{array}$ & 3 & 15 \\
\hline \multirow{2}{*}{$\begin{array}{l}\text { Steps taken to enhance } \\
\text { growth of birds }\end{array}$} & Yes & 20 & 100 \\
\hline & No & 0 & 0 \\
\hline \multirow[t]{2}{*}{ Vaccines used } & ND and IBD & 20 & 100 \\
\hline & Other & 0 & 0 \\
\hline \multirow{2}{*}{$\begin{array}{l}\text { Advice taken from } \\
\text { veterinary doctor }\end{array}$} & Yes & 19 & 95 \\
\hline & No & 1 & 5 \\
\hline
\end{tabular}


To minimize heat stress, $65 \%$ of farmers were using electric fans in the house and normal drinking water for birds, while 35\% farmers supplied vitamin C with cold drinking water. To minimize cold stress $15 \%$ of farmers increased quantities of litter material and supplied vitamin C with drinking water. Similarly, 65\% farmers increased litter materials and added vitamin $C$ in lukewarm drinking water, while $20 \%$ of farmers increased litter materials and supplied warm water as a drink for the birds.

About $85 \%$ of farmers were using oral saline with vitamin $\mathrm{C}$ in water during housing the day-old chicks, while $15 \%$ of farmers were using oral saline, glucose, and vitamin $\mathrm{C}$ in drinking water: interestingly all farmers were using vitamins, amino acids, enzyme, electrolytes, and liver tonic to enhance the growth of broilers. All farmers were using Newcastle Disease (ND) and Infectious Bursal Disease (IBD) vaccines for the commercial hybrid broiler birds and a similar result was reported by Islam et al. (2014). However, 95\% farmers seek advice from veterinary surgeons for better poultry flock health management.

\section{Broiler production performance}

Ross commercial hybrid broiler birds gained a daily average body weight $45.3 \pm 1.2$ $\mathrm{g} /$ bird (Table 3 ) and attained average live weight at marketing age (30 to 35 days) $1581.6 \pm 46.1 \mathrm{~g}$ per bird.

Table 3. Performance of Ross commercial hybrid broilers in rural villages

\begin{tabular}{lc}
\hline \multicolumn{1}{c}{ Traits } & Mean \pm SE \\
\hline Average daily body weight gain in g (ADG) & $45.3 \pm 1.2(20840)$ \\
Feed Conversion Ratio (FCR) & $1.8 \pm 0.1(20840)$ \\
Mortality rate in \% (MTRT) & $5.2 \pm 1.0(21600)$ \\
Live weight at marketing age in g (MW) & $1581.6 \pm 46.1(20840)$ \\
Day Old Chick Weight in g (DOCW) & $54.7 \pm 3.0(21600)$ \\
\hline
\end{tabular}

Average day-old body weight was $54.7 \pm 3.0 \mathrm{~g} /$ bird, mortality up to the age of marketing was $5.2 \pm 1.0 \%$. Feed conversion ratio was $1.8 \pm 0.1$, lower than reported by others (Chand et al., 2009; Jaim and Islam, 2008; Kawsar et al., 2013).

\section{Effects of feed and day-old chick's body weight on performance}

Average daily body weight gain (ADG) was significantly affected by feed company but FCR and MTRT were not (Table 4). Higher ADG $(47.7 \pm 2.8 \mathrm{~g})$ and lower MTRT $(3.9 \pm 1.3 \%)$ were associated with feed from company $\mathrm{O}$ and lower FCR $(1.8 \pm 0.2)$ were recorded for company $\mathrm{N}$. This might be indicative that feed from company $\mathrm{O}$ could help to increase ADG with decreased MTRT but feed from company N could reduce FCR. 
Table 4. Effects of feed and day-old chick body weight on performance of Ross commercial hybrid broilers at rural villages

\begin{tabular}{lcccc}
\hline & ADG (g/day/bird) & FCR & MTRT (\%) \\
\hline Feed company N & $43.1^{\mathrm{b}} \pm 2.3$ & $1.8 \pm 0.2$ & $9.1 \pm 1.1$ \\
Feed company O & $47.7^{\mathrm{a}} \pm 2.8$ & $1.8 \pm 0.9$ & $3.9 \pm 1.3$ \\
LS & $*$ & $\mathrm{NS}$ & NS \\
Small size (40-45gm) & $45.6 \pm 1.7$ & $1.9 \pm 0.1$ & $3.9 \pm 1.3$ \\
Medium size (55-60gm) & $45.9 \pm 2.3$ & $1.8 \pm 0.1$ & $5.1 \pm 1.8$ \\
Large size (65-75gm) & $47.2 \pm 2.3$ & $1.8 \pm 0.1$ & $8.1 \pm 1.8$ \\
\hline LS & $\mathrm{NS}$ & $\mathrm{NS}$ & $\mathrm{NS}$ \\
\hline
\end{tabular}

Note: LS = Level of significance, ab Means with the different superscripts differed significantly within the column $(\mathrm{P}<0.05), \mathrm{NS}=$ Not significance and * $=$ Significance at $5 \%$ level

Body-weight of day-old chicks (DOCW) did not affect ADG, FCR and MTRT significantly (Table 4).

\section{Effects of farm size}

ADG, FCR and MTRT were not affected significantly by farm size (Table 5).

Table 5. Effects of farm size on performance of Ross commercial hybrid broiler at rural villages

\begin{tabular}{lcc|c}
\hline \multicolumn{1}{c}{ Parameters } & ADG & FCR & MTRT \\
\hline Small farm & $44.5 \pm 2.3$ & $1.9 \pm 0.1$ & $7.9 \pm 1.8$ \\
Medium farm & $46.6 \pm 1.7$ & $1.8 \pm 0.1$ & $4.8 \pm 1.3$ \\
Large farm & $46.0 \pm 2.3$ & $1.9 \pm 0.1$ & $3.7 \pm 1.8$ \\
\hline LS & NS & NS & NS \\
\hline
\end{tabular}

Note: LS = Level of significance and NS = Not significant

\section{Effects of education level of farmers}

Education level of farmers did not affect ADG, FCR and MTRT (Table 6).

Table 6. Effects of education on performance of Ross commercial hybrid broiler at rural villages

\begin{tabular}{lcccc}
\hline \multicolumn{1}{c}{ Level of education of farmers } & ADG & FCR & MTRT \\
\hline Junior & $44.3 \pm 1.7$ & $1.9 \pm 11$ & $6.5 \pm 1.5$ \\
Higher secondary & $47.9 \pm 1.6$ & $1.76 \pm 0.1$ & $4.4 \pm 1.4$ \\
Graduate & $44.8 \pm 3.4$ & $2.0 \pm 0.2$ & $4.5 \mathrm{~s} \pm 3.0$ \\
\hline LS & NS & NS & NS \\
\hline
\end{tabular}

Note: LS = Level of significance and NS = Not significance 


\section{Conclusions}

Ross commercial hybrid broilers gained daily average body weight $45.3 \pm 1.2 \mathrm{~g} / \mathrm{bird}$ and attained average live weight at marketing age (30 to 35 days) $1581.6 \pm 46.1 \mathrm{~g} / \mathrm{bird}$. Average day-old body weight was $54.7 \pm 3.0 \mathrm{~g} / \mathrm{bird}$, mortality up to the age of marketing was $5.2 \pm 1.0 \%$. ADG was significantly affected by feed company. However, DOCW, farm size and farmers education did not affect ADG, FCR and MTRT significantly.

\section{Acknowledgements}

Authors would like to thank the farmers of Beltoli, Borobila and Vabkhali villages of Mymensingh Sadar Upazila under Mymensingh district in Bangladesh.

\section{References}

Akter S, Uddin M 2009: Bangladesh poultry industry. Journal of Business and Technology 4 97-112.

Chand V, Chowdhury SD, Saha M, Hossain MK 2009: IFC-SEDF Sector Studies and Baseline Surveys in Poultry in Bangladesh, Final Report. Associates for Development Services Limited, Dhaka, Bangladesh.

Hauque S 2005: Status of broiler farming in Sherpur Sadar Upazila. MS Thesis, Department of Poultry Science, Bangladesh Agricultural University, Mymensingh, Bangladesh.

Islam MK, Uddin MF, Alam MH 2014: Challenges and Prospects of Poultry Industry in Bangladesh. European Journal of Business and Management 6 116-127.

Islam F, Hossain MH, Akhtar A, Hossain MS 2014: Prospect and Challenges in Broiler Farming of Barguna district in Bangladesh. Journal of Bioscience and Agriculture Research 2 44-51.

Jaim J, Islam MN 2008: Impact of technical intervention on profitability of village based medium scaled broiler enterprise in Bangladesh. Progressive Agriculture 19 143-153.

Kawsar MH, Chowdhury SD, Raha SK, Hossain MM 2013: Impact of management intervention on productive performance and profitability of small-scale broiler farming in Bangladesh. Livestock Research for Rural Development 25 (5)

Khaled SMS 2014: Poultry industry: Realities and prospects. The Financial Express, International Publication Limited. http:// www.thefinancialexpress-bd.com

Rahman MM, Islam MR, Ullah MN, Adeyl FMM 2002: Study on the scientific knowledge and management skill in commercial broiler farming program at the farmer level of Rajshahi district. Online Journal of Biological Science 2 767-768.

Sharma RR 2003: A study on the constraints encountered by broiler farmers in Haryana. Indian Journal of Poultry Science 38 302-304.

Sultana F, Khatun H, Islam A 2012: Small scale broiler farming at Santhia Upazilla of Pabna district of Bangladesh. Bangladesh Journal of Animal Science 41 116-119. 